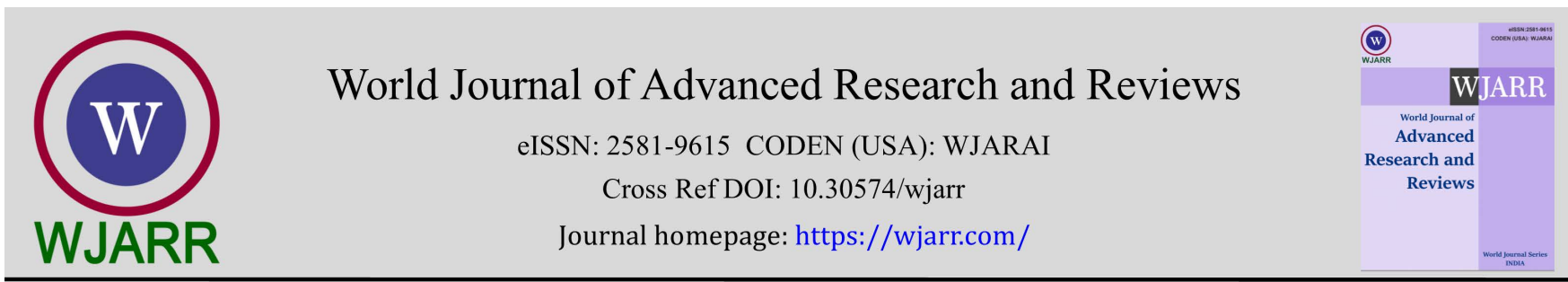

(RESEARCH ARTICLE)

\title{
Evaluation of qualities of extruded snacks from yellow cassava flour substituted with processed sesame seed's flour
}

\author{
Omobolanle Omowunmi Olorode* and Sunday Samuel Sobowale \\ Department of Food Technology, Moshood Abiola Polytechnic, P.M.B. 2210, Abeokuta, Ogun State, Nigeria.
}

World Journal of Advanced Research and Reviews, 2021, 10(01), 074-086

Publication history: Received on 27 February 2021; revised on 31 March 2021; accepted on 04 April 2021

Article DOI: https://doi.org/10.30574/wjarr.2021.10.1.0134

\begin{abstract}
Advocacy on the utilization of locally grown crops keeps increasing. This study was however carried out to evaluate the qualities of extruded snacks from blends of yellow cassava and sesame seeds flour. The yellow fleshed cassava roots and sesame seeds (germinated and fermented) were dried, milled and sieved prior to further analysis. Flour of each of the processed sesame seed was blended with yellow cassava flour at substitution levels of 0,15 and $30 \%$. Functional and anti-nutritional analyses were carried out on the flour blends. The flour blends were mixed thoroughly to produce extruded snacks in a single screw extruder before frying in a deep fryer. Anti-nutrient, proximate and sensory evaluations were carried out on the extruded snacks. There was considerable increase in the functional and proximate compositions with an increase in sesame seed flour incorporation most especially samples with $30 \%$ fermented sesame seeds flours, but with a considerably low anti-nutrient in the extrudates. Extruded samples with $30 \%$ Fermented sesame seed flour also had the highest (7.20) rating with regards to the overall acceptability closely followed by extruded snacks from $100 \%$ yellow cassava flour (7.05) and samples with $30 \%$ germinated sesame seeds flour. The results indicated significant differences $(\mathrm{p}<0.05)$ among the samples. This research revealed that extruded snacks can be produced from non-wheat flours which will reduce over dependence on imported wheat and hence increase the utilization of locally grown crops. It will contribute to large scale production and utilization of the crops for enhanced national food security.
\end{abstract}

Keywords: Extrusion; Yellow cassava; Sesame seed; Extruded snacks; Sensory evaluation

\section{Introduction}

Cassava (Manihot esculenta Crantz) is the third most important source of energy after rice and maize, for human and livestock in the world [1]. It is grown for its edible roots, which serves as a food security and income-generating crop for millions of people in the developing countries [2,3]. Nutritionally, the root is starchy, containing about $60-70 \%$ moisture and $32-35 \%$ total carbohydrate of which $80 \%$ is starch with greater proportion as amylopectin [4]. It has varying amounts of crude fat (0.1-0.3\%), protein (1-3\%) and fibre (1.5\%) depending on the age and variety [5]. Conventional varieties of cassava are deficient in micronutrients such as vitamin A, iron, and zinc thus limiting their use as a single food considering the importance of these micronutrients to humans. This is the major cause of hidden hunger in most parts of Sub-Saharan Africa [6] with over 250 million children under the age of five suffering from vitamin A deficiency $[7,8]$.

Yellow Cassava is bio-fortified with micronutrients which could be a sustainable approach to control micronutrient malnutrition and this could reach the public especially in the tropics through some of the key cassava-based food products. Vitamin A is an essential micronutrient for the normal functioning of visual system, growth and maintenance of epithelial cellular integrity. In developing countries where the supply of animal protein is inadequate to meet the rapid population growth, considerable interests have been shown in supplementing wheat flour with high-protein, high-

\footnotetext{
* Corresponding author: Omobolanle Omowunmi Olorode; Phone: +2348038585545; Email: omobolanleolorode@yahoo.com Department of Food Technology, Moshood Abiola Polytechnic, P.M.B. 2210, Abeokuta, Ogun State, Nigeria. 
lysine material (especially legume and oilseed flours, protein concentrates, and isolates) to increase the protein content and improve the essential amino acid balance of flour-based baked products [9]. These oilseeds and legume can however be utilized in other crops such as cassava to improve its nutrient. In Nigeria, there is a wide varieties of oil crops in various parts of the country ranging from largely known and highly utilized ones like soya bean, palm kernel and groundnut, to underutilized ones like walnut, locust bean, African oil bean and sesame seed.

Sesame (Sesamum indicum Linn) is a major oil crop in the world. Globally, the total crop area under sesame production is about 6 million hectares. Nigeria is the fifth largest producer of sesame seed in the world with an estimated production of 120,000 metric tonnes annually [10]. Black sesame seeds contain better quality of oil and are also suited for medicinal purposes to cure several human diseases [11]. It is exceptionally richer in iron, magnesium, manganese, calcium and Vitamins B1 and B2 [12]. Moreover, evidence also points to the fact that black sesame flour contain significantly lower anti-nutrient (majorly phytate and oxalate). Addition of black sesame seeds flour to root and tuber based products could be a good option to provide better overall essential amino acid balance, helping to overcome the world protein calorie malnutrition problem.

Processes applied to sesame seeds such as roasting, fermentation and germination has been reported to further improve the nutrient quality and reduce the anti-nutrient contents of sesame seeds [13].

Composite flour can be defined as a mixture of flours, starches and other ingredients intended to replace wheat flour totally or partially in bakery and pastry products $[14,15]$. The use of composite flours had a few advantages for developing countries such as saving of hard currency, promotion of high-yielding native plant species, a better supply of protein for human nutrition, better overall use of domestic agriculture production and reduction of importation of wheat flour $[16,17]$. Thus, several developing countries have encouraged the initiation of programmes to evaluate the feasibility of alternative locally available flours as a substitute for wheat flour [18].

Eating snacks during lunch periods has become a way of life for school children and the busy working class people in most urban cities in developing nations like Nigeria. Providing nutritious and healthy snacks remains a major challenge for the food industry to tackle, including the issue of sugar and carbohydrate contents in snack which predisposes obesity [19].

Extrusion cooking is a food process in which ingredients are subjected to mixing, heating and shearing and are forced to flow through a die that forms and expands the ingredients. Effects of extrusion cooking on nutritional quality include changes in proteins and amino acid profile, carbohydrates, dietary fiber, vitamins, mineral content, and some nonnutrient healthful components of food, which may be beneficial [20]. The production of composite flours using various crops for confectionary and bakery goods has been carried out by many researchers. However, very little information is available on the composite flour of Yellow cassava and sesame seed flour for extruded snacks production.

Therefore, the objective of this research was to study the qualities of extruded snacks from Yellow Cassava flour substituted with processed Sesame seeds flour.

\section{Materials and Methodology}

\subsection{Source of materials}

Yellow Cassava roots were sourced from locally trained farmers at the Federal University of Agriculture Abeokuta. Other material such as sesame seeds, wheat flour, sugar, salt and margarine were sourced from Kuto open market in Abeokuta, Ogun State, Nigeria. Extruder used was the locally fabricated extruder of the Department of Food Technology, Moshood Abiola Polytechnic, Abeokuta, Ogun State, Nigeria.

\subsection{Methods}

\subsubsection{Processing of High quality Yellow Cassava flour}

High quality yellow cassava flour was produced using the method described by [21 and 22]. The fleshly harvested yellow cassava roots were weighed, washed, peeled, sliced and blanched at $80^{\circ} \mathrm{C}$ for four minutes. They were dried and milled and then sieved before packaging in a polyethylene film prior to further utilization. 


\subsubsection{Processing of Germinated Sesame Seed Flour}

The method of [12] was adopted for the production of the black sesame seeds flour. Dehulled seeds of black sesame seeds were germinated at room temperatures $\left(25 \pm 2^{\circ} \mathrm{C}\right)$ for 5 days by keeping them in trays lined with wet filter paper. The germinated seeds were dried in a hot air oven at $40^{\circ} \mathrm{C}$ to a constant weight. The samples were milled in an attrition mill to pass through a $0.5 \mathrm{~mm}$ sieve and stored in plastic bags until required for further analysis.

\subsubsection{Processing of Fermented Sesame Seed Flour}

The method of [13] was adopted for the production of the black sesame seeds flour. It was prepared by cooking dehulled seeds of black sesame seeds in boiling water for 6 hours and cooling gradually. The cooked seeds were placed in a plastic container with a lid and sealed after which fermentation took place at temperatures $\left(35 \pm 2^{\circ} \mathrm{C}\right)$ for a period of one week i.e. 7 days. The fermented seeds were dried in an oven set at $105^{\circ} \mathrm{C}$ for 12 hours in order to end the fermentation process. The samples were then milled in an attrition mill to pass through a $0.5 \mathrm{~mm}$ sieve and stored in plastic bags until required for further analysis.

\subsubsection{Sample preparation}

Each of the Germinated and Fermented sesame seed flour was mixed with Yellow cassava flour at levels of 0, 15 and $30 \%$. The blended samples was adjusted to the desired moisture content by spraying calculated amounts of distilled water and mixing thoroughly for $15 \mathrm{~min}$. The samples were packed in polyethylene bags and kept in the refrigerator overnight to equilibrate the moisture. The samples were brought to room temperature before extrusion cooking.

\subsubsection{Extrusion Process}

Extrusion was carried out using a complete line of fabricated extruder, which has a motor coupled with a speed reducer (extrusion by mechanical friction), besides a single extrusion screw, with $130 \mathrm{~mm}$ of barrel diameter, $440 \mathrm{~mm}$ of extruder length, a hydraulic cooling system for temperature control, variable speed, and $50 \mathrm{~kg} \mathrm{~h}^{-1}$ capacity. During the extrusion process a portion of the next test material was used to purge the extruder. The extruded samples were fried in a deep fryer into extruded snacks. Each fried sample was divided into two portions and kept in plastics bags hermetically sealed until evaluation.

\subsection{Sample Analysis}

\subsubsection{Determination of Functional Properties of the Flour Blends}

Water absorption capacity was determined by the method described by [23]. Solubility, swelling capacity and oil absorption capacity were determined using the methods described by [24] while bulk density was determined by the method described by [25].

\subsubsection{Determination of Anti-nutritional and Phytochemical contents of flour blends and extruded snacks}

Tannin content was determined using method described by [26], saponin was determined using standard method by [27], phytate content was determined using method described by [28]. Oxalate and cyanide contents were determined using method described by [29].

\subsubsection{Proximate, dietary fibre and Vitamin A analyses of extruded snacks}

Proximate analysis including moisture, ash, crude protein, fat, dry matter, crude and dietary fibre was determined using [27]. Carbohydrate was determined by difference while dietary fibre and Vitamin A were determined using the method of [30].

\subsubsection{Determination of Crude protein}

Crude protein in the samples was determined by the routine semi-micro Kjeldahl procedure / technique. This consists of three steps of analysis namely; digestion, distillation and titration. $0.5 \mathrm{~g}$ of each finely ground dried sample was weighed carefully into the Kjeldahl digestion tubes to ensure that all sample materials got to the bottom of the tubes.

The percentage nitrogen in this analysis was calculated using the formula: 
The crude protein content was determined by multiplying percentage nitrogen by a constant factor of 6.25 i.e. $\% \mathrm{CP}=$ \% N x 6.25 [27].

\subsubsection{Determination of Crude Fat}

Approximately $1 \mathrm{~g}$ of each sample was weighed into fat free extraction thimble and plugged lightly with cotton wool. The thimble was placed in the extractor and fitted up with reflux condenser and a $250 \mathrm{ml}$ soxhlet flask which has been previously dried in the oven, cooled in the desiccator and weighed.

If the initial weight of dry soxhlet flask is $\mathrm{W}_{0}$ and the final weight of oven-dried flask + oil/fat is $\mathrm{W}_{1}$, percentage fat/oil is obtained by the formula:

$\%$ Crude fat $=\frac{W_{1}-W_{0}}{\text { Weight of sample }} \times 100$

Where; $\mathrm{W}_{0}$ - Initial weight of the flask

$$
\mathrm{W}_{1} \text { - Final weight of the sample }
$$

\subsubsection{Determination of Crude Fibre}

Exactly $2.0 \mathrm{~g}$ of the sample was accurately weighed into the fibre flask and $100 \mathrm{ml}$ of $0.255 \mathrm{~N} \mathrm{H}_{2} \mathrm{SO}_{4}$ added. The mixture was heated under reflux for 1 hour with the heating mantle. The hot mixture was filtered through a fibre sieve cloth. The filtrate obtained was thrown off and the residue was returned to the fibre flask to which $100 \mathrm{ml} \mathrm{of} 0.313 \mathrm{~N} \mathrm{NaOH}$ was added and heated under reflux for another 1 hour.

The percentage fibre was obtained by the formula:

$\%$ fibre $=\frac{W_{1}-W_{2}}{\text { Weight of sample }} \times 100$

Where; $\mathrm{W}_{1}$ - Initial weight of the crucible

$$
\mathrm{W}_{2} \text { - Final weight of the crucible }
$$

\subsubsection{Determination of Total Ash}

In determination of total ash content of each sample, the use of a high temperature muffle furnace capable of maintaining temperatures of between 500 and $600^{\circ} \mathrm{C}$ was utilized. Water and other volatile materials are vaporized and organic substances are burned in the presence of the oxygen in air to $\mathrm{CO}_{2}, \mathrm{H}_{2} \mathrm{O}$ and $\mathrm{N}_{2}$.

$\% \operatorname{Ash}($ dry basis $)=\frac{M_{A S H}}{M_{D R Y}} \times 100$

Where $\mathrm{M}_{\mathrm{ASH}}$ refers to the mass of the ashed sample, and $\mathrm{M}_{\mathrm{DRY}}$ and $\mathrm{M}_{\mathrm{ASH}}$ refer to the original masses of the dried and wet samples

[27].

\subsubsection{Determination of Dry Matter and Moisture}

Two grams of the sample was weighed into a previously weighed crucible. The crucible plus sample taken was then transferred into the oven set at $10^{\circ} \mathrm{C}$ to dry to a constant weight for 24 hours overnight. At the end of the 24 hours, the crucible plus sample was removed from the oven and transferred to desiccator, cooled for 10 min and weighed.

If the weight of empty crucible is $W_{0}$, weight of crucible plus sample is $W_{1}, W_{3}$ is the weight of crucible and sample after drying.

$$
\begin{aligned}
& \% \text { Dry matter }(D M)=\frac{W_{3}-W_{0}}{W_{1}-W_{0}} \times 100 \\
& \% \text { Moisture }=\frac{W_{1}-W_{3}}{W_{1}-W_{0}} \times 100
\end{aligned}
$$


Where; $\mathrm{W}_{0}$ - Initial weight of the crucible

$$
\begin{aligned}
& W_{1}-\text { Weight of crucible + sample } \\
& W_{3}-\text { Weight of crucible + sample after drying }
\end{aligned}
$$

\subsubsection{Determination of Carbohydrate}

Nitrogen free extract/carbohydrate was determined by difference done by subtracting (\% moisture, \% crude protein + $\%$ ether extract $+\%$ crude fibre $+\%$ ash) from 100

$$
\text { i.e. } \quad[100-(\% M+\% C P+\% E E+\% C F+\% A s h)]
$$

\subsubsection{Sensory Evaluation}

Extruded snacks was made from yellow cassava flour substituted with processed sesame seed flour were subjected to sensory evaluation using 25 untrained panelists drawn from Moshood Abiola Polytechnic Abeokuta Community. The extruded snacks were evaluated for colour, aroma, taste, texture, crispiness and overall acceptability. The ratings were on 9 point hedonic scale ranging from 9 (like extremely) to 1(dislike extremely) [31].

\subsection{Statistical analysis}

All analyses except sensory evaluation were carried out in triplicates. The data obtained were subjected to one way analysis of variance (ANOVA). Duncan Multiple Range Test (DMRT) was used to determine the significant difference. All tests were conducted at 5\% significance level and carried out using SPSS (Version 21.0).

\section{Results and discussion}

\subsection{Functional properties of the flour blends}

Functional properties (solubility, foam ability, gelation and emulsification properties etc.) are the intrinsic physicochemical characteristics which may affect the behaviour of food systems during processing and storage. Adequate knowledge of these physicochemical properties indicates the usefulness and acceptability for industrial and consumption purpose [32,33]. The result of the functional properties of the flour blends is as presented in Table 1. The results obtained for $\mathrm{pH}$ of yellow cassava flour (YCF) and processed sesame seed flour ranged from 4.99 to 5.87. It shows that there was significant difference $(\mathrm{p}<0.05)$ between the samples. This shows that YCF was more acidic compared to other substituted samples. Acidic products are more shelf stable than non-acidic counterparts [31]. Similar observations have been made by [34] for wheat and taro flour. The bulk density values ranged from 0.39 to $0.44 \mathrm{~g} / \mathrm{cm} 3 \mathrm{with}$ the highest value found in the sample to be $70 \%$ YCF and 30\% GSSF formulation. There was significant difference in the samples. Generally, bulk density is desirable for greater ease of dispersibility and reduction of paste thickness [35]. The less bulk density, the more packaging space is required [36]. This is because the lower BD value, the higher the amount of flour particles that can stay together and thus increasing the energy content that could be derivable from such diets [37]. The bulk density of the flour samples was observed to increase significantly with increased level of sesame flour at all levels of inclusion for both fermented and germinated sesame seeds flour included samples. The swelling capacity of the flour samples ranged from 14.90 to $16.80 \mathrm{~g} / \mathrm{g}$. There was significant difference $(\mathrm{p}<0.05)$ among the samples when compared with the control. The swelling capacity of the flour samples was observed to increase gradually with increased level of germinated sesame seed flour but reduced with addition of fermented sesame seeds flour to cassava flours. Swelling power is the measure of hydration capacity. This also explains the amount of water needed to change a given amount of flour from its powdered form to its viscoelastic form [38]. This implies that samples with fermented sesame seed flours will swell faster with addition of little amount of water. The water absorption capacity of the flour samples ranged from 145.50 to $166.50 \%$. Flour blend with $15 \%$ germinated sesame seed flour having the highest value while $30 \%$ Fermented sesame seed had the least value. The two processing methods employed on sesame seed in this study had shown to increase significantly the water absorption capacity of the flour samples. The high water absorption capacity observed in the flour samples could be due to the high protein content of the flour as a result of addition of processed sesame seed flour, which has affinity for water molecules [39]. Water absorption capacity is the ability of a product to associate with water under limiting conditions [40]. It has been suggested that flours with such high water absorption capacity as seen in this study is very useful in bakery products, as this could prevent staling by reducing 
moisture loss. The value obtained in this study are within the range (133.33 to 200.00\%) of results obtained by [41] for germinated pigeon pea, fermented sorghum and cocoyam flour blends. The oil absorption capacity of the flour blends ranged from 85.00 to $110.00 \%$. Flour blends containing $30 \%$ germinated sesame seed flour had the highest value while sample with $30 \%$ Fermented sesame seed flour had the least value. Oil absorption capacity is the ability of flour to absorb oil, which is important as oil adds a flavour retainer and improves mouth feel $[42,43]$. The high OAC suggests the lipophilic nature of the constituents of the flour $[44,45]$ and this suggests that the blends most especially those with germinated sesame seeds flour are potentially useful in structural interaction in food especially in flavour retention, improvement of palatability and extension of shelf life of bakery [46]. Solubility is an index of Protein functionality such as denaturation and its potential applications $[33,47]$. The solubility of flour blends ranged from 38.87 to $48.00 \%$. The solubility of the flour samples was observed to increase with increased level of sesame seed flour. There was significant difference $(\mathrm{p}<0.05)$ among the samples. The increase in the solubility of the flour blends might be due to increase in the protein content of the flour blends as the sesame seed flour was been added. Solubility is an index of Protein functionality such as denaturation and its potential applications [47].

Table 1 Functional properties of Yellow Cassava Flour substituted with processed Sesame seed flour

\begin{tabular}{|l|l|l|l|l|l|l|}
\hline Sample & $\mathbf{p H}$ & $\begin{array}{l}\text { Bulk Density } \\
\left(\mathbf{g} / \mathbf{c m}^{3}\right)\end{array}$ & $\begin{array}{l}\text { Swelling } \\
\text { capacity } \mathbf{( g / g )}\end{array}$ & $\begin{array}{l}\text { Water absorption } \\
\text { capacity (\%) }\end{array}$ & $\begin{array}{l}\text { Oil absorption } \\
\text { capacity (\%) }\end{array}$ & $\begin{array}{l}\text { Solubility } \\
(\%)\end{array}$ \\
\hline A & $5.51 \pm 0.04^{\mathrm{b}}$ & $0.39 \pm 0.00^{\mathrm{d}}$ & $15.69 \pm 0.01^{\mathrm{a}}$ & $159.50 \pm 0.70^{\mathrm{b}}$ & $94.50 \pm 2.12^{\mathrm{b}}$ & $38.87 \pm 047^{\mathrm{c}}$ \\
\hline B & $5.87 \pm 0.06^{\mathrm{a}}$ & $0.41 \pm 0.00^{\mathrm{c}}$ & $14.90 \pm 0.35^{\mathrm{b}}$ & $151.50 \pm 2.12^{\mathrm{c}}$ & $88.50 \pm 2.12^{\mathrm{b}}$ & $44.79 \pm 0.32^{\mathrm{b}}$ \\
\hline C & $5.24 \pm 0.04^{\mathrm{c}}$ & $0.42 \pm 0.00^{\mathrm{b}}$ & $15.03 \pm 0.22^{\mathrm{b}}$ & $145.50 \pm 2.12^{\mathrm{d}}$ & $85.00 \pm 1.41^{\mathrm{c}}$ & $44.02 \pm 0.18^{\mathrm{b}}$ \\
\hline D & $5.61 \pm 0.04^{\mathrm{b}}$ & $0.43 \pm 0.00^{\mathrm{ab}}$ & $15.96 \pm 0.09^{\mathrm{a}}$ & $166.50 \pm 2.12^{\mathrm{a}}$ & $107.50 \pm 3.53^{\mathrm{a}}$ & $47.10 \pm 0.82^{\mathrm{a}}$ \\
\hline E & $4.99 \pm 0.06^{\mathrm{d}}$ & $0.44 \pm 0.00^{\mathrm{a}}$ & $16.08 \pm 0.15^{\mathrm{a}}$ & $161.00 \pm 1.41^{\mathrm{b}}$ & $110.00 \pm 4.24^{\mathrm{a}}$ & $48.00 \pm 0.15^{\mathrm{a}}$ \\
\hline
\end{tabular}

Values are means \pm S.D of triplicate determinations. Values in the same column with different superscript are significantly different $(\mathrm{p}<0.05)$ Keys: A-100\% yellow cassava; B-85\% yellow cassava flour, $15 \%$ fermented sesame seed flour; C-70\% yellow cassava flour, 30\% fermented sesame seed flour; D - 85\% yellow cassava flour, 15\% germinated sesame seed flour; E-70\% yellow cassava flour, $30 \%$ germinated sesame seed flour

\subsection{Anti-nutrient composition of the flour blends and extruded snacks}

The results for anti-nutrient composition of yellow cassava processed sesame seed flour blends and extruded snacks are presented in Tables 2 and 3 respectively. Tannins form insoluble complexes with proteins thereby decreasing the digestibility of proteins [48]. The tannin content obtained for the flour blends ranged from 0.030 to $0.044 \%$ while that of the extruded snacks ranged between 0.002 and $0.005 \%$. From this result, it was observed that the tannin content in the flour reduced from 0.030 to $0.005 \%$ in the extruded snacks with significant difference $(p<0.05)$ among the samples. It can therefore be inferred that extrusion cooking caused a drastic reduction of anti-nutrient contents in the extrudates. This result is lower compared to that obtained for high quality cassava-tigernut flour and extrudates $(3.62-6.09$ and $2.46-5.37 \%$ respectively) as reported by [49]. The saponin values for both flour blends and extruded snacks ranged from 0.127 to $0.142 \%$ and 0.094 to $0.119 \%$ respectively. Samples with $15 \%$ fermented sesame seed flour had the most reduced saponin value while extruded snacks made with $100 \%$ YCF had the lowest saponin content. The samples differ significantly by $(\mathrm{p}<0.05)$. The result obtained in this study is lower compared to high quality cassava-tiger nut flour reported by [49] and [50]. Saponins have been reported to be useful in reducing inflammation of upper respiratory passage and also mainly as foaming and emulsifying agents [51] The phytate content of the flour blends and extruded snacks made from yellow cassava flour and processed sesame seed flour ranged from 0.017 to $0.052 \%$ and 0.010 to $0.012 \%$ respectively which differ significantly $(\mathrm{p}<0.05)$. This result indicates that extrusion plays a vital role in phytate reduction. These values were quite lower than the lethal dose for phytate $(250$ to $500 \mathrm{mg} / 100 \mathrm{~g}$ ) reported by [52]. The values agreed reasonably well with [53] who reported that soaking and cooking can reduce phytic acid. Phytates bind minerals in gas to intestinal tract making dietary minerals unavailable for absorption and utilization of the body [54]. It is expected that phytate lowering should enhance the bioavailability of minerals such as iron in extruded snacks as Phytic acid makes such mineral unavailable [55]. 
World Journal of Advanced Research and Reviews, 2021, 10(01), 074-086

Table 2 Anti-nutrient and Dietary fiber Composition of yellow cassava flour-processed sesame seed flour

\begin{tabular}{|l|l|l|l|l|l|l|l|}
\hline Sample & Tannin (\%) & Saponin (\%) & Phytate (\%) & Oxalate (\%) & Trypsin inhibitor (\%) & HCN (\%) & Dietary fibre (\%) \\
\hline A & $0.030 \pm 0.004^{\mathrm{c}}$ & $0.138 \pm 0.002^{\mathrm{a}}$ & $0.017 \pm 0.004^{\mathrm{d}}$ & $0.008 \pm 0.002^{\mathrm{e}}$ & $2.535 \pm 0.077^{\mathrm{b}}$ & $8.320 \pm 0.183^{\mathrm{a}}$ & $2.510 \pm 0.098^{\mathrm{c}}$ \\
\hline B & $0.032 \pm 0.002^{\mathrm{c}}$ & $0.127 \pm 0.002^{\mathrm{b}}$ & $0.030 \pm 0.001^{\mathrm{c}}$ & $0.014 \pm 0.000^{\mathrm{d}}$ & $2.705 \pm 0.049^{\mathrm{b}}$ & $1.265 \pm 0.049^{\mathrm{b}}$ & $3.405 \pm 0.162^{\mathrm{b}}$ \\
\hline C & $0.038 \pm 0.002^{\mathrm{ab}}$ & $0.130 \pm 0.005^{\mathrm{b}}$ & $0.038 \pm 0.002^{\mathrm{b}}$ & $0.021 \pm 0.000^{\mathrm{c}}$ & $2.565 \pm 0.091^{\mathrm{b}}$ & $0.863^{\mathrm{a}} \pm 0.035^{\mathrm{b}}$ & $3.625 \pm 0.091^{\mathrm{b}}$ \\
\hline D & $0.044 \pm 0.000^{\mathrm{a}}$ & $0.141 \pm 0.004^{\mathrm{a}}$ & $0.048 \pm 0.002^{\mathrm{a}}$ & $0.031 \pm 0.001^{\mathrm{b}}$ & $2.935 \pm 0.049^{\mathrm{a}}$ & $0.785 \pm 0.021^{\mathrm{c}}$ & $3.898 \pm 0.021^{\mathrm{a}}$ \\
\hline E & $0.042 \pm 0.002^{\mathrm{a}}$ & $0.142 \pm 0.011^{\mathrm{a}}$ & $0.052 \pm 0.001^{\mathrm{a}}$ & $0.042 \pm 0.001^{\mathrm{a}}$ & $3.038 \pm 0.035^{\mathrm{a}}$ & $0.735 \pm 0.091^{\mathrm{c}}$ & $3.965 \pm 0.077^{\mathrm{a}}$ \\
\hline
\end{tabular}

Values are means \pm S.D of triplicate determinations. Values in the same column with different superscript are significantly different $(\mathrm{p}<0.05)$

Keys: A-100\% yellow cassava; B-85\% yellow cassava flour, 15\% fermented sesame seed flour; C-70\% yellow cassava flour, 30\% fermented sesame seed flour; D - 85\% yellow cassava flour, 15\% germinated sesame seed flour; E-70\% yellow cassava flour, $30 \%$ germinated sesame seed flour

Table 3 Anti-nutrient composition of extruded snacks produced from yellow cassava processed sesame seed flour.

\begin{tabular}{|l|l|l|l|l|l|l|}
\hline Sample & Tannin (\%) & Saponin (\%) & Phytate (\%) & Oxalate (\%) & Trypsin inhibitor (\%) & HCN (\%) \\
\hline A & $0.005 \pm 0.000^{\mathrm{a}}$ & $0.099 \pm 0.002^{\mathrm{cd}}$ & $0.010 \pm 0.000^{\mathrm{c}}$ & $0.085 \pm 0.002^{\mathrm{b}}$ & $855.46 \pm 14.60^{\mathrm{a}}$ & $1.890 \pm 0.028^{\mathrm{a}}$ \\
\hline B & $0.002 \pm 0.000^{\mathrm{c}}$ & $0.119 \pm 0.003^{\mathrm{a}}$ & $0.012 \pm 0.000^{\mathrm{a}}$ & $0.010 \pm 0.000^{\mathrm{c}}$ & $831.17 \pm 2.99^{\mathrm{b}}$ & $1.640 \pm 0.014^{\mathrm{d}}$ \\
\hline C & $0.002 \pm 0.000^{c}$ & $0.094 \pm 0.000^{\mathrm{c}}$ & $0.010 \pm 0.000^{\mathrm{c}}$ & $0.084 \pm 0.001^{\mathrm{b}}$ & $827.24 \pm 0.94^{\mathrm{b}}$ & $1.485 \pm 0.035^{\mathrm{e}}$ \\
\hline D & $0.003 \pm 0.000^{\mathrm{b}}$ & $0.102 \pm 0.000^{\mathrm{b}}$ & $0.011 \pm 0.000^{\mathrm{ab}}$ & $0.093 \pm 0.002^{\mathrm{a}}$ & $856.55 \pm 1.02^{\mathrm{a}}$ & $1.800 \pm 0.014^{\mathrm{b}}$ \\
\hline E & $0.002 \pm 0.000^{c}$ & $0.116 \pm 0.000^{\mathrm{a}}$ & $0.011 \pm 0.000^{\mathrm{ab}}$ & $0.010 \pm 0.000^{\mathrm{c}}$ & $841.54 \pm 0.29^{\mathrm{ab}}$ & $1.735 \pm 0.021^{\mathrm{c}}$ \\
\hline
\end{tabular}

Values are means \pm S.D of triplicate determinations. Values in the same column with different superscript are significantly different $(\mathrm{p}<0.05)$

Keys: A- $100 \%$ yellow cassava; B-85\% yellow cassava flour, $15 \%$ fermented sesame seed flour; C-70\% yellow cassava flour, 30\% fermented sesame seed flour; D - 85\% yellow cassava flour, $15 \%$ germinated sesame seed flour; E-70\% yellow cassava flour, $30 \%$ germinated sesame seed flour 
The oxalate values for the flour blends and extrudates ranged from 0.0080 to $0.0420 \%$ and 0.010 to $0.093 \%$ respectively. There was significant $(\mathrm{p}<0.05)$ difference among the samples. Extruded samples with $15 \%$ Fermented sesame seed flour had the highest value while sample with $30 \%$ germinated sesame seed flour had the least values. These values are quite lower than high quality cassava-tiger nut flour (0.12-0.83 and 0.11-0.63\% respectively) as reported by [49]. Too much of soluble oxalate in the body have been reported to prevents the absorption of soluble calcium ions as the oxalate binds the calcium to form insoluble calcium oxalate complexes. As a result of this, people with the tendency to form kidney stones are advised to avoid oxalate rich foods [56] Trypsin inhibitor values for both the flour blends and extruded snacks ranged from 2.535 to $3.038 \mathrm{~g} / 100 \mathrm{~g}$ and 827.240 to $856.560 \mathrm{mg} / 100 \mathrm{~g}$ respectively. There was significant $(\mathrm{p}<0.05)$ difference among the samples evaluated. This result is relatively high compared to that of yellow maize and soya bean flour blends $(0.06 \mathrm{~g})$ reported by [57]. Hydrogen cyanide values for both the flour blends and extrudates ranged from 0.735 to $8.320 \%$ and 1.485 to $1.890 \%$ respectively. Sample with $100 \%$ YCF had the highest value while sample with $30 \%$ GSSF had the least value while extruded snacks from 30\% Fermented sesame seed flour had the highest value but least in $100 \%$ yellow cassava flour. There was significant $(\mathrm{p}<0.05)$ difference in the samples. This result implies that, extrusion process can cause a reduction in hydrogen cyanide presence in yellow cassava flour. [58] also reported a lower levels of hydrogen cyanide $(0.16$ to $0.24 \mathrm{mg} / 100 \mathrm{~g})$ in cookies made from cocoyam, pigeon pea and sorghum flour blends. Cyanogenic glucoside on hydrolysis yields toxic hydrocyanic acid (HCN). 6 hours of soaking in water reduced the hydrogen cyanide level of cassava flour to $0.863 \%$. Liberated cyanide will usually dissolve in water when fermentation is effected by prolonged soaking [59].

\subsection{Proximate, Dietary fiber and Vitamin A compositions of the extruded snacks}

The result of the proximate composition of extruded snacks produced from yellow cassava-processed sesame seed flour blends is represented in Table 4. The protein content ranged from 7.72 to $10.30 \%$. Extruded snack sample with $30 \%$ Fermented sesame seed flour had the highest value while sample $100 \%$ yellow cassava flour had the least value. The protein values were retained more in the extruded snacks. This might be due to the inclusion of sesame seeds flours which contains high protein. However, extrusion cooking has been discovered to cause relatively small losses of essential amino acids [60]. The fat content which ranged from 10.71 to $13.56 \%$ with the lowest value observed in the control sample was significantly $(\mathrm{p}<0.05)$ different among the samples. The fat content increased as fermented and germinated sesame seed flours was introduced into the yellow cassava flour. Fat is an important component in food because fat improves the flavour and mouth feel of foods [61]. The crude fibre content ranged from 1.80 to $2.20 \%$. Extruded snack with $15 \%$ GSSF had the highest value. There was significant $(\mathrm{p}<0.05)$ difference in the samples. However, too much fibre in the diet is not good for older infants and young children. Fibre has been reported to increase dietary bulkiness, hence limiting adequate food intake by infants and young children [62]. The values obtained in this study were still within the $2.0 \%$ maximum allowable recommend by Nigerian raw materials research and council [63]. The ash content of extruded snacks ranged from 2.19 to $2.77 \%$. There was significant difference in the ash content of the extruded snack samples. Extruded snack sample with $30 \%$ Fermented sesame seed flour had the highest value while sample with $100 \%$ yellow cassava flour had the least value. The high ash content of the extruded snack samples indicates that sesame seed is a good source of mineral element since ash is an indication of mineral element in a food [64]. The result obtained for ash content in this study was in close agreement with that obtained by [65] for cookies produced from pigeon pea-cocoyam flour blends. The moisture content of the extruded snacks ranged from 7.00 to 7.66\%.There was significant difference in the extruded snack samples. These values can be considered low. The low moisture content will give the product good shelf stability. High moisture content has implications on bake products. For example, increased moisture (high moisture content) content would reduce the crispiness of the product [66]. Dry matter is an indicator of the amount of nutrients that are available in a particular food material. The dry matter content of the extruded snacks ranged from 92.34 to $93.00 \%$ in the composite products. The dry matter of the extruded snacks was observed to increase significantly when compared to the control sample. Extruded snacks produced from $30 \%$ Fermented sesame seed flour had the highest value. This could be due to high nutrient density reported in sesame seed which contributed to the nutrient density of the extruded snacks. Sesame seed is rich in fat, protein, carbohydrate, fibre and some minerals [67]. The carbohydrate (CHO) content ranged from 64.37 to $70.49 \%$ with control sample having the highest value. The level of Carbohydrates in the samples may be due to high level of baking fat and yellow cassava flour. The carbohydrate content of the extrudates substituted with processed sesame seeds reduced. Extrusion cooking did not affect carbohydrate content of samples. These values compared well with the results (70.76-79.58\%) obtained by [68], from extrudates of 70 to $90 \%$ sample mixtures of soy and sweet potato for flour. Dietary Fibre is an important dietary component in the diets for adults as it is known to play a role in prevention of constipation, overweight, cardiovascular diseases, diabetes and colon cancer [69]. Dietary fibre of the flours ranged from 2.51 to $3.97 \%$ while that of the extruded snacks ranged from 4.20 to $5.31 \%$. There was significant difference in the samples. The B-carotene (vitamin A) content of the extruded snacks ranged from 0.08 to $0.29 I U$. There was significant $(\mathrm{p}<0.05)$ differences among the samples. Samples with both $15 \%$ and $30 \%$ germinated sesame seeds flour had the lowest values. The Bcarotene which is pro-vitamin $\mathrm{A}$ is an essential nutrient required for maintaining immune function. It also helps in the 
maintenance of healthy teeth, skeletal and soft tissue, mucous membranes and skin. It is often known as retinol because it produces the pigment in the retina of the eye.

Table 4 Proximate, dietary fibre and vitamin A compositions of extruded snacks produced form yellow cassava processed sesame seed flour

\begin{tabular}{|l|l|l|l|l|l|l|l|l|l|}
\hline Sample & $\begin{array}{l}\text { Protein } \\
(\%)\end{array}$ & Fat (\%) & Fibre (\%) & $\begin{array}{l}\text { Total ash } \\
(\%)\end{array}$ & $\begin{array}{l}\text { Moisture } \\
\text { content (\%) }\end{array}$ & $\begin{array}{l}\text { Dry matter } \\
\text { (\%) }\end{array}$ & CHO (\%) & $\begin{array}{l}\text { Dietary } \\
\text { fibre (\%) }\end{array}$ & $\begin{array}{l}\text { Vitamin A } \\
\text { (IU) }\end{array}$ \\
\hline A & $7.72 \pm 0.09^{\mathrm{d}}$ & $10.71 \pm 0.04^{\mathrm{e}}$ & $1.80 \pm 0.07^{\mathrm{b}}$ & $2.19 \pm 0.02^{\mathrm{c}}$ & $7.08 \pm 0.05^{\mathrm{b}}$ & $92.92 \pm 0.05^{\mathrm{a}}$ & $70.48 \pm 0.04^{\mathrm{a}}$ & $4.20 \pm 0.02^{\mathrm{d}}$ & $0.12 \pm 0.01^{\mathrm{c}}$ \\
\hline B & $9.82 \pm 0.07^{\mathrm{b}}$ & $12.78 \pm 0.03^{\mathrm{c}}$ & $1.91 \pm 0.21^{\mathrm{b}}$ & $2.77 \pm 0.04^{\mathrm{a}}$ & $7.08 \pm 0.06^{\mathrm{b}}$ & $92.91 \pm 0.06^{\mathrm{a}}$ & $65.61 \pm 0.02^{\mathrm{c}}$ & $4.32 \pm 0.01^{\mathrm{c}}$ & $0.21 \pm 0.00^{\mathrm{b}}$ \\
\hline C & $10.30 \pm 0.04^{\mathrm{a}}$ & $13.56 \pm 0.09^{\mathrm{a}}$ & $1.94 \pm 0.10^{\mathrm{b}}$ & $2.31 \pm 0.49^{\mathrm{c}}$ & $7.00 \pm 0.11^{\mathrm{b}}$ & $93.00 \pm 0.11^{\mathrm{a}}$ & $64.37 \pm 0.22^{\mathrm{d}}$ & $4.24 \pm 0.02^{\mathrm{cd}}$ & $0.29 \pm 0.01^{\mathrm{a}}$ \\
\hline D & $8.81 \pm 0.27^{\mathrm{c}}$ & $11.72 \pm 0.07^{\mathrm{d}}$ & $2.20 \pm 0.13^{\mathrm{a}}$ & $2.51 \pm 0.42^{\mathrm{b}}$ & $7.66 \pm 0.14^{\mathrm{a}}$ & $92.34 \pm 0.14^{\mathrm{b}}$ & $67.37 \pm 0.22^{\mathrm{b}}$ & $5.31 \pm 0.04^{\mathrm{a}}$ & $0.08 \pm 0.00^{\mathrm{d}}$ \\
\hline E & $9.50 \pm 0.17^{\mathrm{b}}$ & $13.24 \pm 0.05^{\mathrm{b}}$ & $1.95 \pm 0.02^{\mathrm{b}}$ & $2.71 \pm 0.02^{\mathrm{a}}$ & $7.15 \pm 0.06^{\mathrm{b}}$ & $92.84 \pm 0.06^{\mathrm{a}}$ & $65.43 \pm 0.19^{\mathrm{c}}$ & $4.40 \pm 0.02^{\mathrm{b}}$ & $0.14 \pm 0.00^{\mathrm{c}}$ \\
\hline
\end{tabular}

Values are means \pm S.D of triplicate determinations. Values in the same column with different superscript are significantly different $(p<0.05)$ Keys: A-100\% yellow cassava; B-85\% yellow cassava flour, $15 \%$ fermented sesame seed flour; C-70\% yellow cassava flour, 30\% fermented sesame seed flour; D - 85\% yellow cassava flour, 15\% germinated sesame seed flour; E-70\% yellow cassava flour, 30 \% germinated sesame seed flour

\subsection{Sensory Evaluation}

Sensory analysis is a scientific discipline that applies the use of human senses for the purpose of evaluating consumer's acceptability of products qualities [70]. The mean scores for colour, aroma, taste, texture, crispiness and overall acceptability of the extruded snacks samples presented in Table 5 ranged from 5.25 to $7.25,5.85$ to 6.75 , 5.75 to 7.15 , 5.45 to $6.95,6.20$ to 7.20 and 5.85 to 7.20 respectively. Extruded samples with $30 \%$ Fermented sesame seed flour had the highest (7.20) rating with regards to the overall acceptability closely followed by $100 \%$ yellow cassava flour extruded snacks (7.05) on a 9-point hedonic scale rating where 1 represent (dislike extremely) and 9 represents (like extremely). There was significant difference $(\mathrm{p}<0.05)$ in all the attributes tested. Colour is a very important parameter in judging properly food products that do not only reflect the suitability of raw materials used for the preparation but also provides information about the formation and quality of the product. Aroma is a determining factor in consumers' acceptance of food product. Taste refers to the sweet sensation caused in the mouth by contact with the food. It is an important sensory attributes of foods because of its influence on acceptability [71].

Table 5 Sensory scores of extruded snacks made from yellow cassava flour substituted with processed sesame seed flour.

\begin{tabular}{|l|l|l|l|l|l|l|}
\hline Sample & Colour & Aroma & Taste & Texture & Crispiness & Overall acceptability \\
\hline A & $6.90 \pm 1.11^{\mathrm{a}}$ & $5.85 \pm 1.13^{\mathrm{b}}$ & $6.30 \pm 1.83^{\mathrm{ab}}$ & $6.95 \pm 1.35^{\mathrm{a}}$ & $7.20 \pm 1.36^{\mathrm{a}}$ & $7.05 \pm 1.28^{\mathrm{a}}$ \\
\hline B & $6.35 \pm 1.18^{\mathrm{ab}}$ & $5.85 \pm 1.59^{\mathrm{b}}$ & $6.20 \pm 1.73^{\mathrm{ab}}$ & $6.60 \pm 1.93^{\mathrm{a}}$ & $6.20 \pm 2.09^{\mathrm{b}}$ & $5.05 \pm 1.81^{\mathrm{c}}$ \\
\hline C & $7.25 \pm 1.25^{\mathrm{a}}$ & $6.50 \pm 1.82^{\mathrm{a}}$ & $7.15 \pm 1.22^{\mathrm{a}}$ & $6.85 \pm 1.53^{\mathrm{a}}$ & $6.85 \pm 1.08^{\mathrm{a}}$ & $7.20 \pm 1.28^{\mathrm{a}}$ \\
\hline D & $5.25 \pm 2.07^{\mathrm{b}}$ & $5.85 \pm 2.23^{\mathrm{b}}$ & $5.75 \pm 1.80^{\mathrm{b}}$ & $5.45 \pm 1.53^{\mathrm{b}}$ & $6.25 \pm 1.48^{\mathrm{b}}$ & $6.00 \pm 1.71^{\mathrm{ab}}$ \\
\hline E & $6.85 \pm 1.59^{\mathrm{a}}$ & $6.75 \pm 1.77^{\mathrm{a}}$ & $6.05 \pm 2.06^{\mathrm{ab}}$ & $6.65 \pm 1.08^{\mathrm{a}}$ & $6.80 \pm 1.73^{\mathrm{a}}$ & $6.10 \pm 2.38^{\mathrm{b}}$ \\
\hline
\end{tabular}

Values are means \pm S.D of triplicate determinations. Values in the same column with different superscript are significantly different (p<0.05) Keys: A-100\% yellow cassava; B-85\% yellow cassava flour, 15\% fermented sesame seed flour; C-70\% yellow cassava flour, $30 \%$ fermented sesame seed flour; D - 85\% yellow cassava flour, 15\% germinated sesame seed flour; E-70\% yellow cassava flour, $30 \%$ germinated sesame seed flour

The result indicates that in terms of colour, taste, crispiness and overall acceptability, sample with $30 \%$ Fermented sesame seed flour was the most preferred by the panelists. The preference of panelists for the extruded snacks sample with fermented sesame seed flour might be attributed to the influence of fermentation on the flour. Sample with $100 \%$ yellow cassava flour was most preferred in terms of texture. The high mean score obtained for the crispiness of the sample might be due to low moisture content of the sample. [66] stated that high moisture content had an implication on the samples. For example, increased moisture content would reduce the crispiness of fried products. Texture is an important sensory attributes that influences customer selection and acceptability product. Texture is influenced by the physical characteristics of the flours such as particle size. The overall acceptance expresses how the consumers or panelists accept the product generally. The extruded snacks samples were generally accepted by the panel because non falls below 6.00 which is the least acceptable level on a 9-point hedonic scale. Extrusion has been reported to have an organoleptic benefit of changing not only the flavour, aroma and texture but also the physical appearance (colour) of 
cooked products [72]. Generally samples with high amount of fermented and germinated sesame seeds flours were the most acceptable samples among all.

\section{Conclusion}

This study has shown that extruded snacks produced from yellow cassava flour substituted with processed sesame seed flour are nutritionally endowed with reduced anti-nutritional components. Processed sesame seed inclusion in cassava flour did not have any negative effect on the products but rather improved the nutrient contents and sensory attributes of the products. Both flours and extrudates produced with 30\% inclusion of fermented sesame seeds flours to yellow cassava flour were the highest in terms of functionality, nutrient and acceptability. Extrusion cooking also added values to the products in that its transforms them into instant and convenient products with better organoleptic properties. Therefore, extrusion technology should be adopted by small and medium scale food processors. This will contribute to increased production and utilization of the indigenous crops for enhanced food and nutrition security in Nigeria and other developing African countries.

\section{Compliance with ethical standards}

\section{Acknowledgments}

The authors wish to acknowledge the financial support of the Tertiary Education Trust Fund (TETFUND) of the Federal Republic of Nigeria on this research.

\section{Disclosure of conflict of interest}

The authors declare that there are no conflicts of interest regarding the publication of this paper

\section{References}

[1] FAO. Food and Agriculture organisation. Production yearbook. Food and Agriculture Organisation if the United Nations, Rome. 2006.

[2] Sanni LO, Ayinde IA. Consumer acceptance and economic feasibility of dried fufu production in Nigeria. ASSETAn International J. 2002; 3: 107-115.

[3] Amani NG, Kamenan A, Rolland-Sabaté, A, Colonna P. Stability of yam starch gels during processing. African J. Biotechnol. 2005; 4(1): 94-101.

[4] Rawel HM, Kroll J. Die Bedeutung von Cassava (Manihot esculenta, Crantz) als Hauptnahrungsmittel in tropischen Ländern. Deutsche Lebensmittel-Rundschau. 2003; 99: 102- 111.

[5] Charles AL, Sriroth K, Huang TC. Proximate composition, mineral contents, hydrogen cyanide and phytic acid of 5 cassava genotypes. Food Chemistry. 2005; 92(4): 615-620.

[6] Fagbemi TN, Adeoya AS, Badejo AA. Effect of Sulphiting on the Physical and Functional Properties of Acetylated Cassava (Manihot esculenta) Starch. Food Global Science Books. 2012; 6(1): 38-43.

[7] Tanumihardjo SA. Food-based approaches for ensuring adequate vitamin A nutrition. Comprehensive Reviews in Food Science and Safety. 2008; 7: 373-381.

[8] Gegios A, Amthor R, Maziya-Dixon B, Egesi C, Mallowa S, Nungo R, Gichuki S, Mbanaso A, Manary M.J. Children consuming cassava as a staple food are at risk for inadequate zinc, iron, and vitamin A intake. Plant Foods for Human Nutrition. 2010; 65: 64-70.

[9] Young J. Functional bakery products: current directions and future opportunities. Food Industries Journal. 2001; 4: 136-144.

[10] NCRI. Oil seeds research divisional report. National cereal research institute. Annual Review meeting. 10-13.

[11] Leung, A. Chinese Healing Foods and Herbs. http:// leungschineseherbs.blogspot.part-2-open-sesamesesameseed-that-is.html. 
[12] Makinde FM, Akinoso R. Nutrient composition and effect of processing treatments on anti-nutritional factors of Nigerian sesame (Sesamum indicum Linn) cultivars. International Food Research Journal. 2013; 20(5): 22932300 .

[13] Makinde F, Akinoso R. Physical, nutritional and sensory qualities of bread samples made with wheat and black sesame (Sesamum indicum Linn) flours. International Food Research Journal. 2014; 21(4): 1635-1640.

[14] Milligan ED, Amlie JH, Reyes J, Garcia A, Meyer B. Processing for production of edible soy flour. Journal American Oil Chemistry Social. 1981; 58: 331.

[15] Shittu T, Raji AO, Sanni LO. Bread from composite cassava-wheat flour: I. Effect of baking time and temperature on some physical properties of bread loaf. Food Research International. 2007; 40: 280-290.

[16] Bugusu BA, Campanella O, Hamaker BR. Improvement of sorghum-wheat composite dough rheological properties and breadmaking quality through zein addition. Cereal Chemistry. 2001; 78(1): $31-35$.

[17] Hasmadi M, Siti Faridah A, Salwa I, Matanjun P, Abdul Hamid M, Rameli AS. The effect of seaweed composite flour on the textural properties of dough and bread. Journal of Applied Phycology. 2014; 26: 1057-1062.

[18] Abdelghafor RF, Mustafa AI, Ibrahim AMH, Krishnan PG. Quality of bread from composite flour of sorghum and hard white winter wheat. Advance Journal of Food Science and Technology. 2011; 3: 9-15.

[19] Emmanuel-Ikpeme C, Eneji C. Igile G. Nutritional and organoleptic properties of wheat (Triticum aestivum) and beniseed (Sesame indicum) composite flour baked foods. Journal of Food Research. 2012; 1: 3.

[20] Singh S, Gamlath S, Wakeling L. Nutritional aspects of Food extrusion: A review. International Journal of Food Science and Technology. 2007; 42(8): 916 - 929.

[21] Graham AE, Dziedzoave N, Avenor GS. Expand markets for locally produced cassava flour and starches in Ghana.Final technical report for CPHP project R6504. Joint Report of the National Resources Institute and food research Institute. 2000; 40-45.

[22] IITA. Post- harvest Technology. Annual report. 2010; 62-80.

[23] Sathe SK, Desphande SS, Salunkhe DK. Functional properties of Lupin seed (Lipinus mutabilis) Protein and protein concentrates. Journal of food Science. 1982; 47: 491-497.

[24] Leach HW, McCowen LD, Scoch TJ. Structure of starch granule, swelling and solubility patterns of various starches. Cereal Chemistry. 1959; 36: 534-544.

[25] Akpapunam MA, Markakis P. Physiochemical and nutritional aspects of Cowpea flour. Journal of Food Science. 1987; 46: 972-973.

[26] Swain T. Tannins and Lignins. In: Rosenthal, G. A., Jansen, D. H. (ed.) Herbivores, their interaction with secondary plant metabolites. Academic Press. New York. 1979; 65-74.

[27] AOAC. Official Methods of Analysis. 19th Edn. Association of Official Analytical Chemists, Washington, DC, USA. 2005.

[28] Maga JA. Phytate: Its Chemistry, Occurrence, Food interactions, Nutritional Significance and Method of Analysis. J. Agri. Food Chem. 1983; 30: 1-9.

[29] Bradbury MG, Egan SV, Bradbury JH, Determination of all forms of cyanogens in cassava roots and cassava products using picrate paper kits. J. Sci. Food Agric. 1999; 79: 593 - 601.

[30] Tell DA, Hagarty M. Soil and plant analysis. University of Guelph/International Institute for Tropical Agriculture, Ibadan, Nigeria publication. 1984; 227.

[31] Ihekoronye AI, Ngoddy PO. Integrated Food Science and Technology for the Tropics, Macmillan Publishers Limited, London. 1985; 236-253.

[32] Fasasi OS, Eleyinmi AF, Oyarekua MA. Effect of some traditional processing operations on the functional properties of African breadfruit seed (Treculia africana) flour. LWT. 2017; 40: 513-519.

[33] Olorode 00, Idowu MA, Ilori OA. Effect of Benoil (Moringa oleifera) Leaf Powder on the Quality Characteristics of 'Ogi'. American Journal of Food and Nutrition. 2013; 3: 2.

[34] Ikpeme-Emmanuel CA, Osuchukwu NC, Oshiele L. Functional and sensory properties of wheat (Aestium triticium) and taro flour (Colocasia esculenta) composite bread. Afr. J. Food Sci. 2010; 4: 248-253. 
[35] Udensi EA, Okoronkwo KA. Effects of fermentation and germination on the physicochemical properties of Mucuna cochinchinensis protein isolate. African Journal of Biotechnology. 2006; 5(10): 896-900.

[36] Agunbiade S0, Ojezele MO. Quality evaluation of instant breakfast cereals fabricated from maize, sorghum, soybean and African yam bean (Sphenostylis stenocarpa). World J. Dairy and Food Sci. 2010; 5: 7-72.

[37] Onimawo IA, Egbekun KM. Comprehensive Food Science and Nutrition. Revised Edition, Ambik publishers, Benin City. 1998; 103-208.

[38] Daramola B, Osanyiniusi SA. Investigation on modification of cassava starch using active components of ginger roots (Zingiber officinale Roscoe) African journal of Biotechnology. 2006; 5(10): 917-920.

[39] Yusuff AA, Ayedun H, Sanni LO. Chemical composition and functional properties of raw and roasted Nigerian benniseed (Sesamum indicum) and Bambara groundnut (Vigna subterranean). Food Chem. 2008; 111: 227-282.

[40] Singh S. Nutritional aspects of food extrusion: a review, International Journal of Food Science and Technology. 2001; 42: 916-929.

[41] Okpala I, Okoli E, Udensi E. Physicochemical, and sensory properties of cookies made from blends of germinated pigeon pea, fermented sorghum, and cocoyam flours. Food Science and Nutrition. 2013; 1(1): 8-14.

[42] Odoemelam SA. Chemical composition and functional properties of conophor nut (Tetracarpidium conophorum) flour. Int. J. Food Sci. Technol. 2003; 38: 729-734.

[43] Aremu MO, Olaofe 0, Akintayo ET. Functional properties of some Nigerian varieties of legume seed flours and flour concentration effect on foaming and gelation properties. J. Food Technol. 2007; 5: 109-115.

[44] Ubbor SC, Akobundu ENT. Quality characteristics of cookies from composite flours of watermelon seed, Cassava and Wheat. Pakistan Journal of Nutrition. 2009; 8(7): 1097-1102.

[45] Olorode 00, Idowu MA, Bamgbose A, Ayano AE. Chemical, Phytochemical and Functional Properties of Selected Seeds' Flours. International Journal of Nutrition and Food Sciences. 2014; 3 (6): 572-578.

[46] Seena S, Sridhar KR. Physicochemical, functional and cooking properties of under explored legumes, Canavalia of the southwest coast India. Food Res. Int. 2005; 38: 803-814.

[47] Omueti O, Otegbayo B, Jaiyeola O, Afolabi O. Functional properties of complementary diets developed from soybean (Glycine max), Groundnut (Arachis hypogeal and Crayfish (Macrobrachium spp). J. of Environ. Agric. And Food Chem. 2009; 8(8): 563-573.

[48] Uzeochina OB. Evaluation of the effect of processing techniques on the nutrient and antinutrients contents of pigeon pea (Cajanus cajan) Seed flours. J. Food Sci. 2007; 28: 76-77.

[49] Adebowale AA, Sanni LO, Kuye A. Effect of roasting methods on sorption isotherm of tapioca grits. Electronic J. Environ. Agric. Food Chem. 2006; 5(6): 1649-1653.

[50] Nwaguikpe RN. The phytochemical, proximate and amino acid compositions of the extracts of two varieties of tiger nut (Cyperus esculentus) and their effects on sickle cell hemoglobin polymerization. J.Med. Med. Sci. 2010; 1: 543-549.

[51] Frantisek SS. The Natural Guide to Medicinal Herbs and Plants. Tiger Barks Cast, Twinkemhan, United Kingdom. 1991; 1-5.

[52] Bushway RJ, Bureau JL, McGann DP. Determination of Organic Acid in Potatoes by High Performance Liquid Chromatography. Journal of Food Science. 1984; 49: 75-77.

[53] Bishnoi S, Khetarpaul N, Yadav RK. Effect of domestic processing and cooking methods on phytic acid and polyphenol content of peas. Plant Foods Hum. Nutr. 1994; 45(4): 381-388.

[54] Lew MN, Adebola PO, Afolayan AJ. Effect of cooking on the proximate composition of the leaves of some accessions of Colocasia esculenta (L) Schoot in Kwazulu-Natal province of South Africa. Africa J Biotechnol. 2009; 8: $1619-1622$.

[55] Anuonye JC, Onuh JO, Egwim E, Adeyemo SO. Nutrient and Antinutrient Composition of Extruded Acha/Soybean Blends. Journal of Food Processing and Preservation. 2009; 34(s2): 680-691.

[56] Adeniyi SA, Orjiekwe CL, Ehiagbonare JE. Determination of alkaloids and oxalates in some selected food samples in Nigeria. Afri. J. Biotechnol. 2009; 8(1): 110-112. 
[57] Nkesiga J. Production and evaluation of extruded snacks from yellow maize soybean carrot and amaranth leaf flour blends. A master thesis submitted to the Department of Food Science and Technology, Faculty of Agriculture, University of Nigeria, Nsukka. 2014.

[58] Okpala LC, Okoli EC. Nutritional evaluation of cookies produced from pigeon pea, cocoyam and sorghum flour blends. African Journal of Biotechnology. 2011; 10(3): 433-438.

[59] Casadei R. Nutritional and toxicological aspects of cassava. In Walter, R. \& Quattruci, E. eds. Nutritional and toxicological aspects of food processing, Taylor and Francis London. 1988; 171-176.

[60] Harper JM. Food Extrusion. CRC Crit. Rev. Food Sci. Nutri. 1997; 155-215.

[61] Odoemelam SA. Proximate Composition and Selected Physicochemical Properties of the Seeds of African Oil Bean (Pentaclethra marcrophylla). Pakistan Journal of Nutrition. 2005; 4: 6382-383.

[62] Hofvander Y, Underwood BA. Nutrition and health: Processed supplementary foods for older infants and young children, with special reference to developing countries. Food and Nutrition Bulletin. 1987; 9(1): 1-6.

[63] RMRDC. Report on Survey of Agro-Raw Material in Nigeria Beniseed. Raw Materials Research And Development Council, Abuja, USA. 2004; 99.

[64] EL-Adawy TA. Nutritional composition and Anti nutritional Factors of Chick peas (Cicer arietinium L) undergoing different cooking methods and germination Plant foods for Human Nutrition (Formerly Qualitas Plantarium). 2002; 57(1): 83-87.

[65] Okpala LC, Chinyelu VA. Phsicochemical, Nutritional and organoleptic evaluation of cookies from pigeon pea (Cajanus cajan) and cocoyam (Xanthosoma spp) flour blends. African Journal of Food, Agriculture, Nutrition and Development. 2011; 11(6): 5431-5443.

[66] Shittu TA, Edema MO, Dada O, Atayese AO. Microorganisms associated with the spoilage of pupuru. Food Control. 2010; 21: 203-206.

[67] Global Agri systems. Dehulled and roasted sesame seed oil processing unit. 18 August 2010.

[68] Iwe MO, Ngoddy PO. Proximate Composition and Some Functional Properties of Extrusion Cooked Soybean and Sweet Potato Blends. Plant Foods for Human Nutrition. 1998; 53: 121-132.

[69] Whitney EN, Hamilton EM, Rolfes SR. Understanding Nutrition, 5th Edition. West publishing company, New York. 1990; 629.

[70] Meilgaard M, Civille GV, Carr BJ. Sensory Evaluation Techniques (4th edn.). Boca Raton; CRC Press. 2007 ; 488.

[71] Olapade AA, Adeyemo AM. Evaluation of cookies produced from blends of wheat, cassava and cowpea. International Journal of Food Studies. 2014; 3(2): 175-185.

[72] Jones JM. Breakfast Cereals and How They Are Made. Fast, E.F and Caldwell, E.F. (eds.). The American Association of Cereals Chemists. 2003. 